\title{
PERGERAKAN ZONA KONVERGENSI DI SAMUDERA PASIFIK BAGIAN BARAT BERDASARKAN DATA INSITU DAN SATELIT
}

\author{
CONVERGENCE ZONE DISPLACEMENT IN WESTERN PACIFIC OCEAN \\ BASED ON INSITU AND SATELLITE DATA
}

\author{
Faisal Hamzah, Eko Susilo, Iis Triyulianti dan Agus Setiawan \\ Balai Penelitian dan Observasi Laut, Balitbang KP, KKP \\ Jl. Baru Perancak, Negara, Jembrana, Bali 82251 \\ E-mail: faisalhamzah@kkp.go.id dan ekosusilo@live.com
}

Diterima tanggal: 3 Maret 2014, diterima setelah perbaikan: 24 Juni 2015, disetujui tanggal: 26 Juni 2015

\begin{abstract}
ABSTRAK
Samudera Pasifik berperan penting dalam siklus El-Nino Southern Oscillation (ENSO) dan berpengaruh signifikan pada kegiatan penangkapan tuna di Indonesia, khususnya ikan Cakalang. Penelitian ini bertujuan mengetahui pola pergerakan zona konvergensi di Samudera Pasifik bagian Barat dengan mengamati pergerakan parameter oseanografi seperti suhu, salinitas, klorofil-a, dan produktivitas primer. Data parameter oseanografi tersebut terdiri dari data insitu, data satelit maupun hasil pemodelan. Hasil analisis menunjukan adanya pergerakan zona konvergensi di Barat Pasifik yang dicirikan variabel proksi yaitu isotermal $29^{\circ} \mathrm{C}$, isohalin $34,6 \mathrm{psu}$, konsenrasi klorofil-a sebesar $0,1 \mathrm{mg} / \mathrm{m}^{3} \mathrm{dan} \mathrm{NPP} 300$ $\mathrm{mgC} / \mathrm{m}^{2} /$ day. Pola pergerakan zona konvergensi baik secara horisontal maupun vertikal dipengaruhi oleh ENSO. Pada saat terjadi La-Nina massa air dengan suhu yang hangat bergeser ke arah Barat yang diikuti dengan meningkatnya kesuburan perairan. Pergerakan vertikal massa air hangat terjadi pada kedalaman 25-75 m (suhu) dan $50 \mathrm{~m}$ (salinitas). Namun pada saat El-Nino massa air hangat bergerak ke arah Timur Samudera Pasifik. Fluktuasi produksi tangkapan ikan Cakalang di perairan Indonesia Timur mengikuti pola pergerakan zona konvergensi tersebut. Peningkatan jumlah produksi ikan Cakalang di Kota Sorong meningkat seiring dengan keberadaan zona konvergensi di bagian Barat (LaNina), namun di Propinsi Papua menunjukan pola sebaliknya.
\end{abstract}

Kata kunci: zona konvergensi, Samudera Pasifik, ENSO.

\begin{abstract}
Pacific Ocean have an important role on El-Nino Southern Oscillation (ENSO) phenomena that have significant relationship with tuna fisheries in Indonesian waters, especially for skipjack tuna. The aim of this study is to determine convergence zone displacement in Western Pacific Ocean based on oceanography parameters such as temperature, salinity, chlorophyll-a, and net primary productivity from insitu, satellite and model data. The convergence zone displacement in Western Pacific Ocean were characterized by proxies variable of isotherm $29{ }^{\circ} \mathrm{C}$, isohaline $34,6 \mathrm{psu}$, chlorophyll-a concentration $0,1 \mathrm{mg} / \mathrm{m}^{3}$ and NPP $300 \mathrm{mg} \mathrm{C} / \mathrm{m}^{2} /$ day. Whole of these displacement influenced by ENSO event. The warm pool displacement westerly during La-Nina event accompanied with increasing marine primary productivity. The vertical movement of warm pool occurred on 25-75m depth for temperature and $50 \mathrm{~m}$ depth for salinity. Otherwise, during the El-Nino event the warm pool move to eastward. The fluctuation of skipjack tuna production in eastern of Indonesian Waters following the convergence zone displacement in Western Pacific Ocean. The increasing of skipjack tuna productions in Sorong increase due to convergence zone in the western part of Pacific (La-Nina), meanwhile for the Papua's skipjack tuna production show the opposite.
\end{abstract}

Keywords: convergence zone, Pacific Ocean, ENSO.

Pergerakan Zona Konvergensi di Samudera Pasifik Bagian Barat Berdasarkan Data Insitu dan Satelit -

Faisal Hamzah, Eko Susilo, Iis Triyulianti dan Agus Setiawan 75 


\section{PENDAHULUAN}

Samudera Pasifik berperan penting dalam siklus El-Nino Southern Oscillation (ENSO) dan iklim dunia (Lehodey et al., 1997). Fenomena ENSO memberikan pengaruh yang signifikan kepada kegiatan penangkapan di Indonesia. Hal ini erat kaitannya dengan adanya pergerakan kolam air hangat di Samudera Pasifik bagian Barat yang sangat dipengaruhi oleh pola angin pasat (trade wind). Pada kondisi normal angin pasat berhembus dari Timur dan Tenggara menuju ke Samudera Pasifik bagian Barat yang membangkitkan arus permukaan dan aliran massa air dari Timur ke Barat di sepanjang ekuator Samudera Pasifik. Kondisi ini menyebabkan tumbuhnya permukaan air hangat di Samudera Pasifik bagian Barat yang dikenal sebagai kolam air hangat Pasifik Barat (West Pacific Warm Pool). Selain itu angin menyebabkan terjadinya percampuran air permukaan yang hangat dengan lapisan yang lebih dalam (mixed layer) yang dicirikan dengan lapisan termoklin pada kedalaman sekitar 100 meter atau lebih di Samudera Pasifik bagian Barat. Sementara itu di Samudera Pasifik bagian Timur, massa air yang dingin yang berasal dari lapisan yang lebih dalam naik di lepas pantai Amerika Selatan untuk mengisi massa air yang terbawa ke Barat dan menghasilkan lapisan termoklin yang dangkal, sekitar 10-50 meter (Setiawan, 2002).

Kolam air hangat Pasifik Barat memiliki zona konvergensi permanen di bagian Timurnya. Zona konvergensi ini dicirikan oleh adanya front suhu dan salinitas permukaan laut, pola arus dan konsentrasi nutrien sebagai akibat pertemuan dua massa air yang berbeda yaitu massa air dingin dengan salinitas yang lebih tinggi dari Samudera Pasifik ekuatorial bagian Tengah dan Timur yang bertemu dengan massa air hangat dengan salinitas rendah dari Samudera Pasifik ekuatorial bagian Barat. Perpindahan massa air secara zonal (BaratTimur) dari zona konvergensi tersebut terjadi mengikuti siklus ENSO. Pada saat El-Nino zona konvergensi ini berpindah ke arah Timur, sebaliknya pada saat La-Nina berpindah ke arah Barat (Lehodey et al., 1997).

Sebagaimana diketahui, zona konvergensi dan front merupakan kombinasi mekanisme yang sangat penting bagi plankton dan mikronekton dan tuna sebagai salah satu predatornya. Lehodey et al.
(1997), menyatakan pergerakan kolam air hangat di Samudera Pasifik bagian Barat mempengaruhi kelimpahan ikan Cakalang (Katsuwonus pelamis) di Perairan Indonesia bagian Timur. Supangat et al. (2004) menyatakan bahwa terdapat korelasi antara kelimpahan relatif ikan cakalang dengan variabel proksi untuk zona konvergensi yang meliputi isotermal $29^{\circ} \mathrm{C}$ suhu permukaan laut, isohaline 34,6 psu dan kejadian ENSO. Variabel proksi ini digunakan karena data time series yang bersifat menerus baik terhadap waktu dan ruang. Penelitian ini bertujuan mengetahui pola pergerakan zona konvergensi di Samudera Pasifik bagian Barat. Selain itu pengetahuan mengenai pola pergeseran kolam air hangat dapat digunakan sebagai dasar penentuan prediksi keberadaan ikan cakalang hingga beberapa bulan ke depan.

\section{BAHAN DAN METODE}

Identifikasi pola pergerakan zona konvergensi menggunakan analisis hovmoller diagram berdasarkan front suhu permukaan laut, konsentrasi klorofil-a, salinitas dan produktivitas primer perairan. Hovmoller diagram mampu menggambarkan data-data oseanografi secara time series berdasarkan longitude maupun latitude dengan lebih baik. Lokasi penelitian difokuskan di Samudera Pasifik bagian Barat (Warm Pool West Pacific) dan Perairan Indonesia bagian Timur seperti Utara Papua, Laut Maluku, Laut Halmahera, Laut Seram dan Laut Banda (Gambar $1)$.

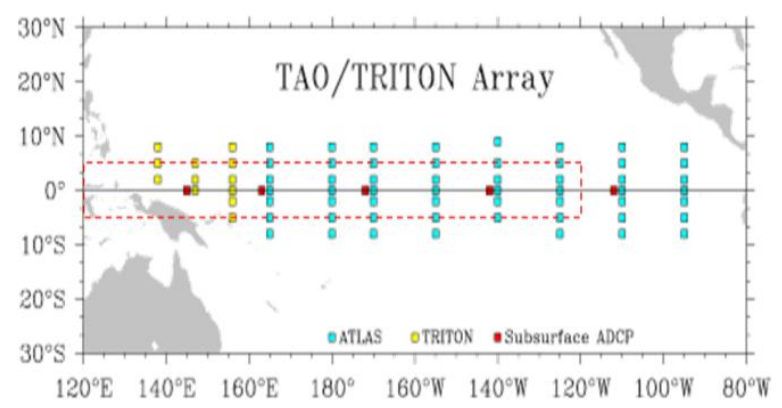

Gambar 1. Lokasi penelitian

Figure 1. Study site

Sumber: http://www.pmel.noaa.gov/tao/

Analisis hovmoller diagram menggunakan rasterVis package pada perangkat lunak $\mathrm{R}$ (Lamigueiro \& Hijmans, 2013). R adalah perangkat lunak tak berbayar untuk komputasi 
statistik dan grafik (http://www.r-project.org/). Batasan penggambaran hovmoller diagram meliputi area antara $5{ }^{0} \mathrm{~N}-5{ }^{0} \mathrm{~S}$ dan $120{ }^{0} \mathrm{E}-120{ }^{0} \mathrm{~W}$ (Gambar 1) yang merupakan daerah zona konvergensi (Lehodey et al., 1997). Periode waktu pangamatan mulai bulan Juli 2002 sampai dengan Desember 2012. Nilai rata-rata variabel data suhu permukaan laut (SPL), salinitas (SAL), konsentrasi klorofil-a (CHL), dan Net Primary Production (NPP) pada longitude yang sama kemudian digambarkan pada hovmoller diagram.

Data suhu permukaan laut dan konsentrasi klorofila menggunakan citra Aqua MODIS bulanan Level 3 Global Standard Mapped Image (SMI). Data tersebut memiliki ukuran grid 4320 x 8640 dengan resolusi $1 / 24$ derajat $(4 \mathrm{~km})$ baik latitude maupun longitude. Data tersebut dapat di unduh melalui portal: http://oceandata.sci.gsfc.nasa.gov/. Data produktivitas primer perairan menggunakan data hasil model Standart-Vertically Generalized Production Model (VGPM). VGPM adalah standar model untuk mengestimasi produktifitas primer $\left(\mathrm{mgC} / \mathrm{m}^{2} /\right.$ day) yang "berbasis klorofil-a" dengan menggunakan data konsentrasi klorofil-a dan suhu permukaan laut (MODIS), Photosynthetically Available Radiation (seaWiFS) dan kedalaman zona eufotik (Behrenfeld \& Falkowski, 1997). Data VGPM memiliki ukuran grid 2160 x 4320 dengan resolusi $1 / 12$ derajat baik latitude maupun longitude dalam format hdf diunduh melalui http://www.science.oregonstate.edu/ocean.producti vity/index.php.

Selain analisis pergerakan massa air di permukaan juga dilakukan analisis profil vertikal suhu dan salinitas menggunakan data pengukuran mooring TAO/TRITON di Samudera Pasifik. Data suhu dan salinitas diunduh melalui portal http://www.pmel.noaa.gov/tao/. Dalam penelitian ini, kedalaman yang diambil adalah $1 \mathrm{~m}, 25 \mathrm{~m}, 50$ $\mathrm{m}, 75 \mathrm{~m}$ dan $100 \mathrm{~m}$. Hal ini dilakukan berdasarkan pada habitat ikan Cakalang di lapisan tercampur di atas termoklin (Lehodey et al., 1997). Periode waktu pangamatan mulai bulan Januari 2000 sampai dengan Desember 2012. Data suhu dan salinitas berupa data rata-rata harian dalam format ASCII. Data suhu dan salinitas kemudian dirataratakan selama satu tahun di tiap kedalaman berdasarkan posisi lintang dan tahun.

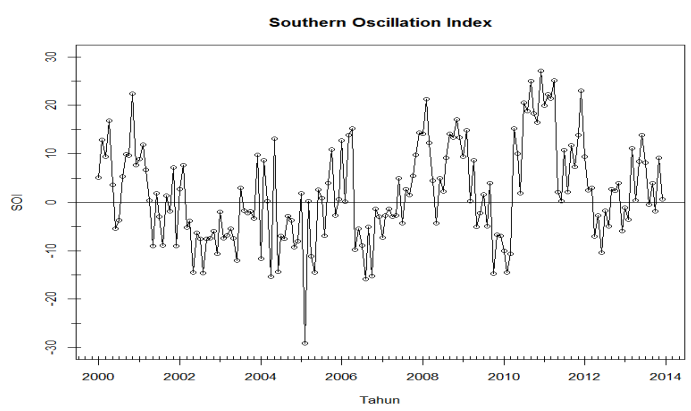

Gambar 2. Southern Oscillation Index, 2000-2013.

Figure 2. Southern Oscillation Index, 2000-2013 Sumber : http://www.bom.gov.au/climate/current/soi2.shtml

Analisis pengaruh pergerakan zona konvergensi terhadap volume produksi tangkapan ikan cakalang di Perairan Indonesia bagian Timur melalui data pendaratan ikan cakalang di Provinsi Papua dan Kota Sorong. Pendataan masing-masing dilakukan oleh Dinas Kelautan dan Perikanan Provinsi Papua dan Dinas Kelautan dan Perikanan Kota Sorong. Data tangkapan ikan cakalang yang digunakan adalah data rata-rata bulanan dari tahun 2007-2012. Analisis data tangkapan ikan Cakalang bulanan tersebut dikaitkan dengan Southern Oscillation Index (SOI). SOI memberikan informasi mengenai indikasi dan intensitas kejadian El-Nino dan LaNina di Samudera Pasifik berdasarkan perbedaan tekanan di Tahiti dan Darwin (Treenberth, 1997). Periode El Nino ditandai oleh nilai SOI negatif (SOI $<-8$ ), sedangkan periode La-Nina ditandai oleh nilai SOI positif $(\mathrm{SOI}>+8)$. Nilai SOI selama kurun waktu 2000-2013 disajikan pada Gambar 2.

\section{HASIL DAN PEMBAHASAN}

Pergerakan massa air di laut dapat terjadi secara horizontal maupun vertikal, masing-masing proses tersebut mempunyai karakteristik yang berbeda untuk suhu, salinitas, atmosfer, dan tekanan. Perbedaan karakteristik tersebut akan berpengaruh terhadap kondisi atau habitat ikan. Pada umumnya ikan mempunyai karakteristik tersendiri terhadap lingkungannya di laut. Apabila ikan-ikan tersebut bergerak di luar habitat mereka, maka pertumbuhan dan tingkat kelangsungan hidupnya akan menurun. Ikan Cakalang umumnya beradaptasi pada lapisan permukaan yang hangat, sedangkan big eye mempunyai habitat di lapisan dalam yang dingin (Brill et al., 2005). 


\section{Pergerakan Horizontal Zona Konvergensi}

Hasil analisa data citra dengan menggunakan hovmoller diagram terhadap parameter SPL, CHL, NPP dan SAL periode tahun 2002-2012 pada area $5{ }^{0} \mathrm{~N}-120{ }^{0} \mathrm{E}, 5{ }^{0} \mathrm{~S}-120{ }^{0} \mathrm{~W}$ terlihat dengan jelas adanya pergerakan massa air di sepanjang ekuator Samudera Pasifik. Pada Gambar 3a, ditunjukkan adanya perbedaan nilai SPL di bagian Barat Pasifik dengan Timur Pasifik. Pada bagian Barat Pasifik memiliki SPL lebih hangat $\left(>28,5{ }^{\circ} \mathrm{C}\right)$, sedangkan bagian Tengah dan Timur Pasifik cenderung lebih dingin. Perbedaan tersebut ditandai oleh isoterm 29 ${ }^{0} \mathrm{C}$. Pola yang sama juga dapat dilihat pada hovmoller diagram salinitas (Gambar 3b), dimana pergerakan salinitas ke arah Barat dan Timur Pasifik menunjukan terjadinya ENSO. Bagian Barat Pasifik dicirikan oleh nilai salinitas yang rendah (33,5-34,6 psu), sedangkan bagian Tengah dan Timur Pasifik dicirikan oleh salinitas yang tinggi (> 35,2 psu). Perbedaan massa air tersebut ditandai oleh isohaline 34,6 psu.

Pola pergerakan isoterm $29{ }^{\circ} \mathrm{C}$ dan isohalin 34,6 psu mengikuti perubahan nilai SOI. Pada saat lapisan isoterm $29{ }^{0} \mathrm{C}$ menuju ke bagian Tengah dan Timur Pasifik, nilai SOI negatif yang mengindikasikan terjadinya El-Nino seperti terjadi pada tahun 2010. Pada tahun 2008 lapisan isoterm $29{ }^{\circ} \mathrm{C}$ bergeser menuju ke Barat Pasifik dan nilai SOI positif yang mengindikasikan terjadinya La Nina (Gambar 3a). Hal yang sama juga terjadi pada tahun 1990-1991 dan 1995 saat terjadi LaNina dan tahun 1992-1994 saat terjadi El-Nino. Pada saat terjadi La-Nina, SOI naik dari 0 hingga 1,5 saat terjadi El-Nino berkisar antara 0 hingga -1 (Lehodey et al., 1997). Daerah zona konvergensi yang diamati setiap tahunnya berubah berdasarkan bujur. Jika dilihat kembali hovmoller diagram SPL, pergerakan massa air pada saat El-Nino dan LaNina mempunyai batas pada bujur $160{ }^{\circ} \mathrm{E}-160{ }^{\circ} \mathrm{W}$. Pada saat La Nina (2006, 2008, dan 2011-2012), zona konvergensi mempunyai batas $160{ }^{0} \mathrm{E}$. Pada saat El Nino (2007 dan 2010), zona konvergensi mempunyai ujung batas hingga bujur $160{ }^{0} \mathrm{~W}$. Pergerakan massa air dipengaruhi oleh angin pasat (trade wind) yang berasal dari Timur dan Tenggara Pasifik, baik North Equatorial Current (NEC) dan South Equatorial Current (SEC), yang menuju ke bagian Barat Pasifik dan kembali lagi dari Barat menuju ke Tengah dan Timur Pasifik (Stewart, 2002). Semakin besar angin dari Barat Pasifik berhembus, maka daerah zona konvergensi yang terbentuk juga akan semakin besar. Sebaliknya, semakin kecil angin dari Barat berhembus, maka zona konvergensi yang terbentuk akan semakin kecil.

Rendahnya nilai salinitas pada bagian Barat Pasifik merupakan implikasi ENSO (Picaut et al., 1996). Pada saat El Nino (Juli 2002, 2005 dan 2010), salinitas bergerak ke arah Tengah dan Timur Pasifik. Namun berbeda saat La Nina (2006, 2008 dan 2012), massa air dengan salinitas rendah bergerak kearah Barat Pasifik. Perpindahan secara zonal salinitas lebih terlihat dan bervariasi pada bujur $140{ }^{0} \mathrm{E}-160{ }^{0} \mathrm{~W}$. Pada Gambar 3e (hasil tumpang tindih Gambar 3a dan 3b) dengan parameter salinitas $34,6 \mathrm{psu}$, dapat dilihat pula adanya proses adveksi (gerakan transfer horisontal) dari Barat Pasifik yang ditandai oleh suhu yang hangat $\left(29^{\circ} \mathrm{C}\right)$ dan salinitas yang rendah $(34,6$ psu) dan bertemu dengan massa air dari TengahTimur Pasifik dengan suhu yang lebih rendah $(<$ $28{ }^{\circ} \mathrm{C}$ ) dan salinitas lebih tinggi (> 34,6 psu). Hal ini bisa dilihat lebih rinci melalui Gambar 3e pada Juli 2002, 2005, 2007, dan 2010. Picaut et al., (1996), mengobservasi proses ini dengan cara memasang buoy-drifter dengan lokasi $4{ }^{0} \mathrm{~S}-4{ }^{0} \mathrm{~N}$ pertengahan 1988-1993 dan hasilnya adalah trajektori buoy drifter ini mengikuti pergerakan pinggir Timur warm pool khususnya pada suhu 29 ${ }^{0} \mathrm{C}$ dan salinitas 34,6 psu. Proses adveksi tersebut akan berasosiasi dengan El Nino dan La Nina serta variasi arus permukaan yang nantinya akan menumbuhkan suatu zona konvergensi di bagian pinggir kolam air hangat (eastern edge of warm pool) yang kaya akan produktivitas primer (Picaut et al., 1996).

Berdasarkan Gambar 3c dan 3d, terlihat adanya pergerakan massa air kearah Timur-Barat Pasifik yang mempengaruhi kesuburan perairan yang ditandai oleh pergerakan CHL $\left(0,1 \mathrm{mg} / \mathrm{m}^{3}\right)$ dan NPP (300 $\mathrm{mgC} / \mathrm{m}^{2} /$ day). Pergerakan massa air yang membawa CHL dan NPP dari arah Timur Pasifik menuju Barat dapat dilihat pada tahun 2006, 2008 dan 2011-2012. Sedangkan tahun 2003, 2005, 2007, 2010 dan pertengahan 2012, terjadi pergerakan zona konvergensi yang membawa CHL dan NPP dari Barat Pasifik menuju Tengah dan Timur. Wilayah pergerakan CHL berada pada batas $160{ }^{0} \mathrm{E}-160{ }^{0} \mathrm{~W}$. Pengaruh pergerakan massa air tersebut sangat dipengaruhi oleh daerah divergen di Pasifik bagian Tengah dan 
Timur dimana massa air dingin dari lapisan dalam akan bergerak menuju ke permukaan dan membawa nutrien yang tinggi. Selain itu, karena pasokan nutrien yang tinggi, maka fitoplankton akan tumbuh subur di daerah ini dan akan banyak ikan-ikan kecil yang memakan plankton tersebut. Hal ini akan mengundang predator pelagis (tuna, billfish dan hiu) bergerak ke lapisan permukaan untuk memakan ikan kecil tersebut (Grandperrin, 1978). Dengan adanya angin pasat, maka daerah divergen akan bergerak kearah Barat Pasifik.

Konsentrasi CHL dan NPP sepanjang bujur $130{ }^{\circ} \mathrm{E}$ dari pertengahan tahun 2002 hingga 2012 mempunyai nilai yang tinggi (Gambar 3c dan Gambar 3d). Daerah ini merupakan Perairan Indonesia yang subur meliputi Laut Arafura, Laut Halmahera dan Laut Maluku. Hal yang sama juga dapat dilihat pada bujur $130{ }^{\circ} \mathrm{W}$ dimana nilai NPP tinggi dan mencapai kisaran 400-700 $\mathrm{mgC} / \mathrm{m}^{2} /$ day (Gambar 3d). Tingginya nilai CHL dan NPP di wilayah Perairan Indonesia sangat dipengaruhi oleh angin monsun dan diduga menjadi salah satu faktor yang menyebabkan terkonsentrasinya ikan cakalang di wilayah tersebut. Bunyamin (1981), menyatakan bahwa penyebaran ikan cakalang terdapat pada lintang $10{ }^{0} \mathrm{~S}-5{ }^{0} \mathrm{~S}$ yang meliputi Laut Sulawesi, Laut Maluku, Laut Halmahera, Laut Flores, Laut Sawu, Laut Timor, Laut Arafura dan Perairan utara Papua dengan batas antara $5{ }^{0} \mathrm{~N}-1{ }^{0} \mathrm{~S}$ dan 131-146 ${ }^{0}$ E. Daerah potensial penyebaran ikan cakalang di perairan utara Papua tersebar antara $1^{0} \mathrm{~S}-4^{0} \mathrm{~N}$, tetapi lebih terkonsentrasi pada daerah antara $0-2^{0} \mathrm{~N}$ (Waas, 2004).

Daerah Pasifik bagian Barat merupakan oligotropik yang miskin akan nutrien, namun kelimpahan ikan cakalang di daerah ini sangat tinggi (Lehodey et al., 1997). Hal ini lebih disebabkan oleh adanya zona konvergensi yang luas yang mampu mendukung kelangsungan hidup ikan cakalang. Zona konvergensi ditandai oleh mikronekton dan bahan organik. Sebagian nutrien dan fitoplankton yang berasal dari zona divergen di bagian Pasifik Tengah akan terbawa oleh massa air menuju daerah konvergensi hingga jarak 1800$2500 \mathrm{~km}$ (Lehodey et al., 1997).

Maes et al., (2010) meneliti mengenai kandungan klorofil-a di bagian Barat Pasifik yang dilakukan pada saat survey Frontalis-3 tahun 2005, hasil observasi tersebut menunjukan nilai klorofil-a tinggi pada kedalaman 60-100 $\mathrm{m}$ yang berasal dari bagian Tengah Pasifik. Massa air yang mengandung klorofil-a tersebut bergerak dari tengah menuju Barat Pasifik (zona konvergensi), terutama pada wilayah $160{ }^{0} \mathrm{E}-163{ }^{0} \mathrm{E}$. Tingginya nilai klorofil-a tersebut disebabkan oleh stabilitas massa air yang kuat pada kolom perairan dan juga dikontrol oleh salinitas. Stratifikasi ini dihasilkan sama dengan efek sebagai lapisan batas (barrier layer) dan mencegah masuknya massa air dingin ke lapisan permukaan yang berasal dari lapisan termoklin yang kedalamannya lebih dari $100 \mathrm{~m}$ (Maes et al., 2010). Nutrien yang berasal dari lapisan bawah tidak mampu naik ke permukaan (eufotic zone) dan tidak dapat meningkatkan produktivitas primer pada perairan tersebut.

Matsumoto \& Ando (2009), menemukan hubungan yang erat antara proses fisik dan proses biologi pada lapisan permukaan di Barat Pasifik. Hasil yang sama juga telah dilakukan oleh Maes et al. (2010) yang menggunakan data argo float tahun 2002-2004 serta data citra SeaWIFS dan Modis/Aqua dimana hasilnya adalah konsentrasi klorofil-a yang tinggi. Hasil penelitian Maes et al., (2010) menunjukan bahwa selama periode 19982006, perpindahan secara zonal klorofil-a lebih terlihat dan bervariasi pada bujur $140{ }^{\circ} \mathrm{E}-160{ }^{\circ} \mathrm{W}$. Zona konvergensi yang dibatasi oleh suhu, nutrien dan front salinitas dapat dijadikan sebagai monitoring ENSO. Hal tersebut di deteksi oleh daerah pinggir paling timur kolom air hangat. Berdasarkan data klorofil-a, daerah pinggir paling timur kolam air hangat bisa dideteksi jika konsentrasinya adalah $0,1 \mathrm{mg} / \mathrm{m}^{3}$ (Maes et al., 2010). Pada diagram hovmoller CHL juga menunjukan pergerakan Barat-Timur pada konsentrasi $0,1 \mathrm{mg} / \mathrm{m}^{3}$. Fenomena ENSO yang kuat pada periode tahun 1997-1998, berpengaruh pada proses biogeokimia di ekuatorial Pasifik (Chavez et al., 1999). Daerah transisi pada Barat Pasifik bisa dikenali pada pada suhu perairan yang hangat yaitu lebih dari $28{ }^{\circ} \mathrm{C}$ (Maes et al., 2010). Pada periode tersebut, CHL akan bergeser hingga 20 derajat ke arah Barat dibandingkan dengan menggunakan isoterm $28{ }^{0} \mathrm{C}$. Hal yang berbeda dengan yang dilakukan oleh Waliser (1996) dalam Maes et al., (2010), dimana daerah transisi pada Barat Pasifik memiliki suhu lebih panas dari 29,75 ${ }^{0} \mathrm{C}$. Pada umumnya, keterkaitan pergerakan $\mathrm{CHL}$ pada daerah transisi selain dipengaruhi oleh arus, juga dipengaruhi oleh variabilitas salinitas. 

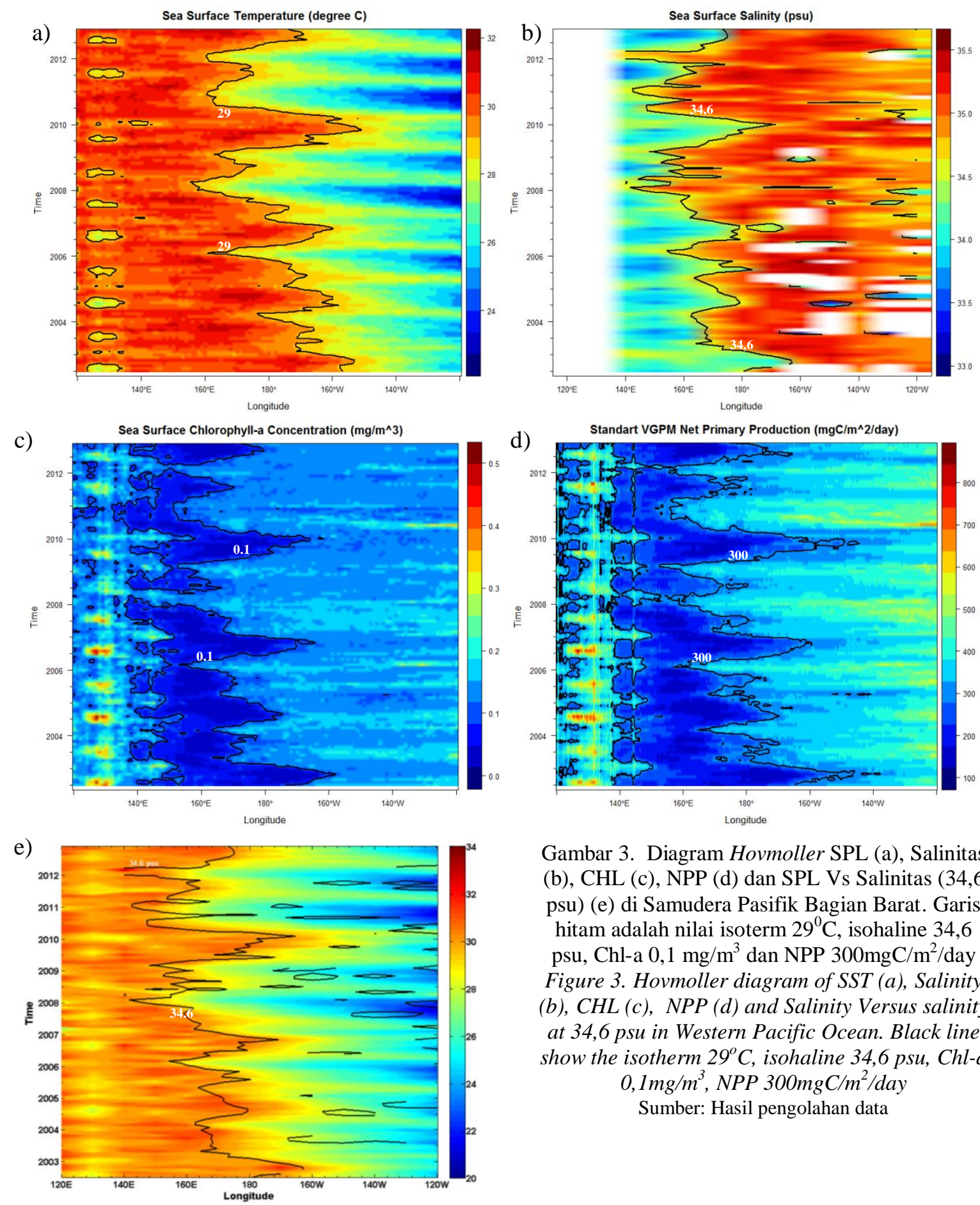

Gambar 3. Diagram Hovmoller SPL (a), Salinitas (b), CHL (c), NPP (d) dan SPL Vs Salinitas (34,6 psu) (e) di Samudera Pasifik Bagian Barat. Garis hitam adalah nilai isoterm $29^{\circ} \mathrm{C}$, isohaline 34,6 psu, Chl-a $0,1 \mathrm{mg} / \mathrm{m}^{3}$ dan NPP $300 \mathrm{mgC} / \mathrm{m}^{2} /$ day Figure 3. Hovmoller diagram of SST (a), Salinity (b), CHL (c), NPP (d) and Salinity Versus salinity at 34,6 psu in Western Pacific Ocean. Black line show the isotherm $29^{\circ} \mathrm{C}$, isohaline 34,6 psu, Chl-a $0,1 \mathrm{mg} / \mathrm{m}^{3}, \mathrm{NPP} 300 \mathrm{mg} \mathrm{C} / \mathrm{m}^{2} /$ day Sumber: Hasil pengolahan data

\section{Pergerakan vertikal massa air}

Hasil pengolahan dan analisis profil suhu dan salinitas pada kedalaman $0-100 \mathrm{~m}$ dari data TAO array yang terletak pada lintang $0 \mathrm{~N}, 2 \mathrm{~S}, 2 \mathrm{~N}, 5 \mathrm{~N}$ dan $5 \mathrm{~S}$ pada bujur $150{ }^{0} \mathrm{E}-110^{0} \mathrm{~W}$ selama kurun waktu sepuluh tahun terakhir (2000-2011) menunjukkan adanya pergerakan vertikal massa air di Samudera Pasifik bagian Barat. Pada Gambar 4, Gambar 5, Gambar 6, Gambar 7, dan Gambar 8

memperlihatkan profil suhu, pada daerah Ekuator $\left({ }^{0} \mathrm{~N}\right)$ menunjukkan terjadinya pergerakkan masa air hangat (isoterm $28-29{ }^{\circ} \mathrm{C}$ ) baik secara vertikal dan horizontal. Pergerakkan kolom massa air hangat suhu $29{ }^{0} \mathrm{C}$ di daerah ekuator lintang $0{ }^{0} \mathrm{~N}$ menunjukan pergerakan horizontal kearah Barat dan pergerakan vertikal dari layer $25 \mathrm{~m}$ hingga layer $65 \mathrm{~m}$ dari tahun $2000 \mathrm{ke}$ tahun 2001. Hal yang sama juga terlihat pada lintang $5 \mathrm{~N}, 2 \mathrm{~N}, 2 \mathrm{~S}$, 
dan 5S. Pola pergerakan massa air pada tahun 2000 secara horizontal mempunyai batas kolom air hangat berada di sekitar $170^{\circ} \mathrm{E}$. Pada tahun 2001, 2002 dan 2003 kolam air hangat bergeser kearah Timur di sekitar $160{ }^{0} \mathrm{~W}$. Batas kolom air hangat kemudian bergeser ke Barat di sekitar $180{ }^{\circ} \mathrm{E}$ pada tahun 2004-2007. Selanjutnya pada tahun 2008 dan 2011 batas kolom air hangat bergeser kembali ke arah Barat di sekitar $170{ }^{0} \mathrm{E}$, sementara itu pada tahun 2009 dan 2010 batas tersebut kembali bergeser ke Timur berada disekitar $170{ }^{0} \mathrm{~W}$.

Pergeseran batas kolom air hangat secara vertikal sangat erat hubungannya dengan kejadian La-Nina dan El-Nino. Pada kondisi normal, kolom air hangat di Ekuator Samudera Pasifik berada di sekitar $170{ }^{0} \mathrm{~W}$. Pada saat El-Nino, batas kolom air hangat tersebut bergerak menuju Timur, sedangkan pada saat La-Nina, kolom air hangat tersebut bergerak kearah Barat. Pergerakan tersebut juga bisa dilihat berdasarkan SOI. Pada tahun 20022003 terjadi El-Nino $\quad(\mathrm{SOI}<-8)$ dan ini menyebabkan kolam air hangat bergerak kearah Timur. Hal yang sama juga diduga dengan pergerakan ikan cakalang dimana akan bermigrasi mengikuti pergerakan massa air dari barat menuju timur (Lehodey et al., 1997). Pada saat El-Nino, adanya pergerakan massa air dengan suhu yang lebih hangat menuju Timur (Pasifik bagian Tengah) kemudian bagian pinggir dari warm pool akan berosilasi pada $180{ }^{\circ} \mathrm{W}$ dengan perpindahan massa air yang besar dari timur dan ini akan berkorelasi dengan sinyal ENSO, kadang perpindahan tersebut lebih dari 50 derajat (Lehodey et al., 1997). Pada tahun 2007-2008 (SOI>8) dan 2010-2011 (SOI>8) terjadi La-Nina, pada saat itu kolom air hangat bergerak menuju barat dan diduga penyebaran ikan cakalang akan berada di bagian Barat Samudera Pasifik. Lehodey et al. (1997), memperlihatkan pergerakan ikan cakalang pada saat La Nina ke arah Barat Pasifik. Ikan cakalang tersebut ditandai (tagging) pada Maret 1992, kemudian ditangkap kembali sebelum Oktober 1992 dengan dominansi pergerakan menuju kearah Barat Pasifik.

Jika massa air pada Gambar 4, Gambar 5, Gambar 6, Gambar 7, dan Gambar 8 dilihat secara spasial, semakin kearah Barat Samudera Pasifik, suhu umumnya menjadi lebih hangat $\left(>28{ }^{0} \mathrm{C}\right)$ dan mempunyai variabilitas musiman kurang dari $1{ }^{\circ} \mathrm{C}$. Di daerah Tengah dan Timur Samudera Pasifik, massa air lebih dicirikan oleh suhu yang rendah dibandingkan suhu di sebelah Barat Samudera Pasifik. Proses divergensi di bagian Tengah hingga timur diduga sebagai penyebab hal di atas. Proses ini diduga membawa nutrien yang tinggi hingga ke permukaan. Massa air juga membawa khlorofil-a yang tinggi dan mengindikasikan tingkat produktivitas primer. Daerah tersebut sering dikenal dengan istilah "cold tongue". Bagian Barat Samudera Pasifik yang lebih hangat, salinitas dan nutrien yang rendah akan bergerak menuju ke Timur dan dipengaruhi oleh angin barat dan daerah bagian Timur yang berbatasan dengan cold tongue dikenal dengan istilah tropical convergence zone. Zona ini bisa diidentifikasi dengan front salintas dan suhu isoterm $29{ }^{\circ} \mathrm{C}$. Supangat et al., (2004) juga menganalisa daerah konvergensi di Pasifik pada tahun 1993 dengan mengidentifikasi front salinitas dan isoterm 28-29 ${ }^{\circ} \mathrm{C}$ dimana daerah konvergensi begerak pada $163{ }^{0} \mathrm{E}-150{ }^{\circ} \mathrm{W}$ dan 13 ${ }^{0} \mathrm{~S}-6{ }^{0} \mathrm{~N}$ pada bulan Januari-Maret. Pada bulan April daerah konvergensi bergerak ke Barat dan berada pada $165{ }^{0} \mathrm{E}-158{ }^{0} \mathrm{~W}$ dan $8{ }^{0} \mathrm{~S}-5{ }^{0} \mathrm{~N}$ hingga bulan Mei mencapai $156{ }^{0} \mathrm{E}$. Pada periode September-Desember, daerah konvergensi semakin ke arah selatan $\left(163{ }^{0} \mathrm{E}-164{ }^{0} \mathrm{~W}\right.$ dan $\left.13{ }^{0} \mathrm{~S}-3{ }^{0} \mathrm{~N}\right)$.

Keberadaan daerah potensial ikan cakalang satu daerah memiliki karakteristik yang berbeda. Suhu optimal untuk ikan cakalang di Pasifik bagian Barat berada pada kisaran $29{ }^{\circ} \mathrm{C}$ (Lehodey et al., 1997), hal ini berbeda dengan di bagian Selatan pesisir Brazil dimana ikan cakalang yang ditangkap berada pada kisaran suhu $17-30{ }^{\circ} \mathrm{C}$ (Andrade \& Garcias, 1999). Di perairan Tasmania dan Tenggara Australia, ikan cakalang ditangkap pada suhu $15-18{ }^{\circ} \mathrm{C}$, di Perairan Jepang dan Selatan Amerika pada suhu $20-24{ }^{0} \mathrm{C}$ serta di Selatan India pada suhu $28-29{ }^{\circ} \mathrm{C}$ (Barkley et al., 1978). Di Perairan Indonesia, ikan cakalang bisa tumbuh pada suhu $26-32{ }^{\circ} \mathrm{C}$, dan suhu yang ideal untuk melakukan pemijahan adalah pada $28-29{ }^{\circ} \mathrm{C}$ dengan salinitas 33 psu (Gunarso, 1985). Di Perairan Teluk Palabuhan Ratu, ikan cakalang banyak tertangkap pada kisaran suhu $25-29{ }^{0} \mathrm{C}$ (Limbong, 2008). Dizon (1977) menganalisis suhu $15{ }^{\circ} \mathrm{C}$ merupakan batas bawah lethal untuk ikan cakalang. Jika suhu dibawah $15{ }^{\circ} \mathrm{C}$, maka ikan cakalang tidak bisa hidup. Batas maksimal ikan cakalang mampu hidup adalah $33{ }^{\circ} \mathrm{C}$. Ikan cakalang mempunyai sistem metabolisme untuk beradaptasi dengan lingkungannya terutama perbedaan suhu dengan menggunakan insang. Selain itu, ikan cakalang juga sangat bergantung 
pada kandungan oksigen terlarut. Umumnya ikan cakalang menyukai perairan yang memiliki nilai
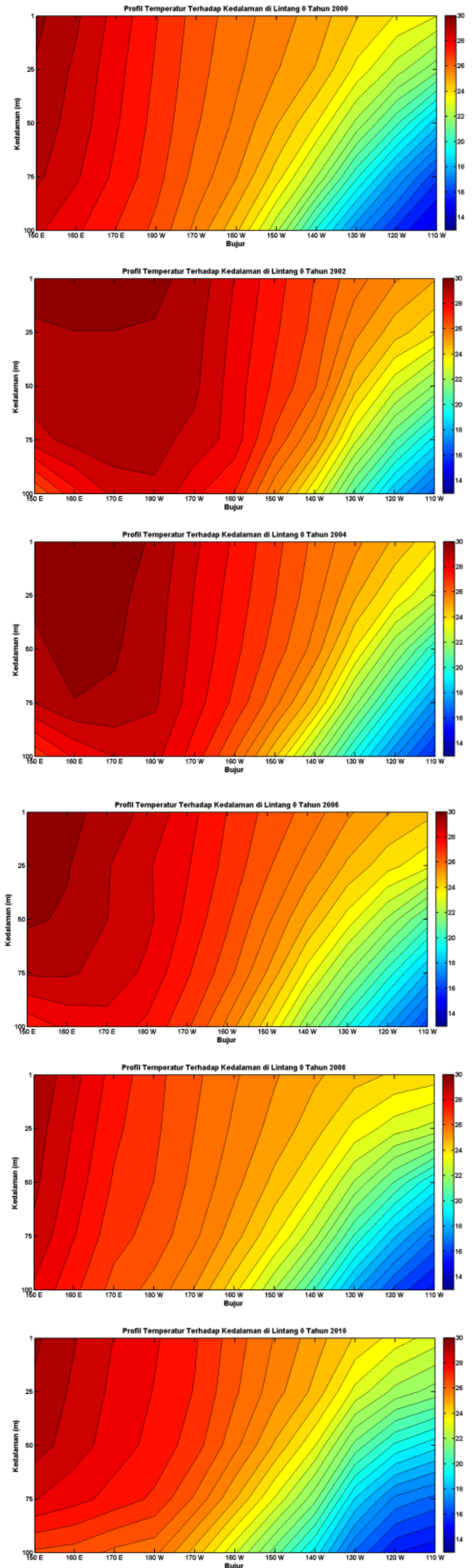

oksigen terlarut sekitar $4,5 \mathrm{ml} \mathrm{O} / \mathrm{L}$ atau $6,4 \mathrm{ppm}$ (Barkley et al., 1978).
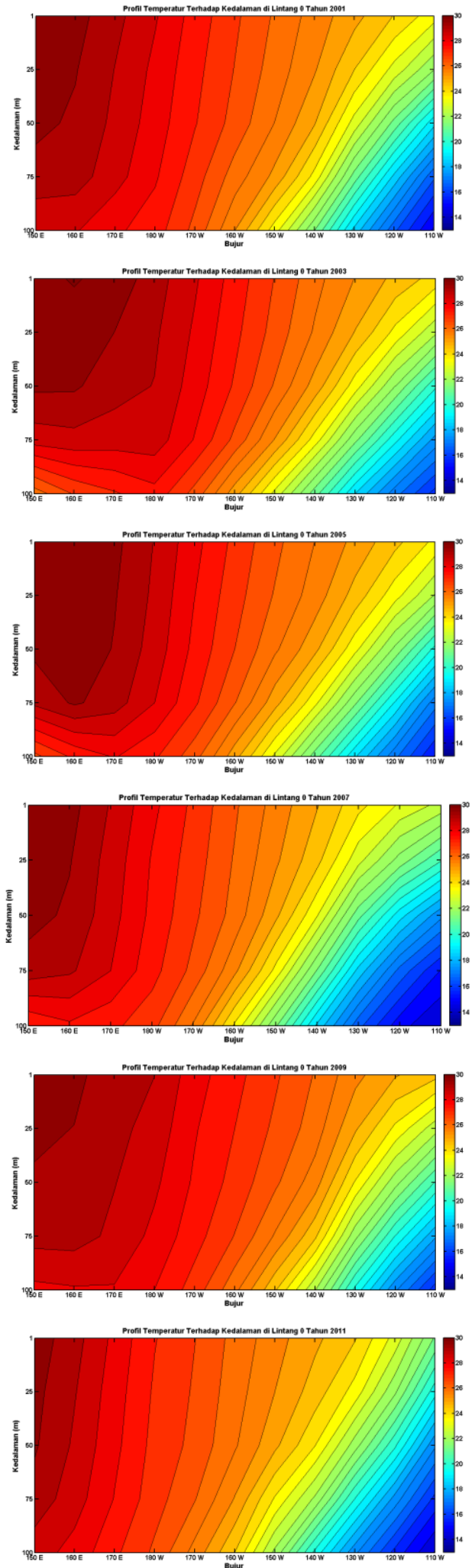

Gambar 4. Rata-rata tahunan suhu $\left({ }^{\circ} \mathrm{C}\right)$ pada tahun 2000-2012 di lintang $0^{0}$. Figure 4. Annual averaged of temperature $\left({ }^{\circ} \mathrm{C}\right)$ during 2000-2012 at $0^{0}$ Sumber: Hasil pengolahan data 

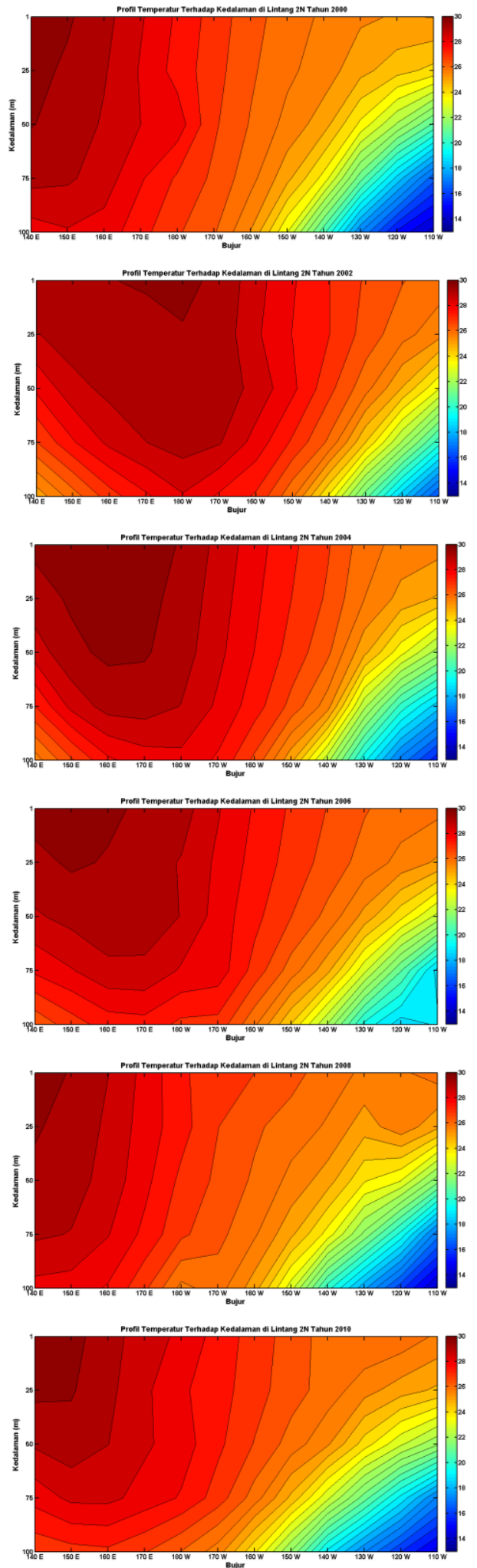
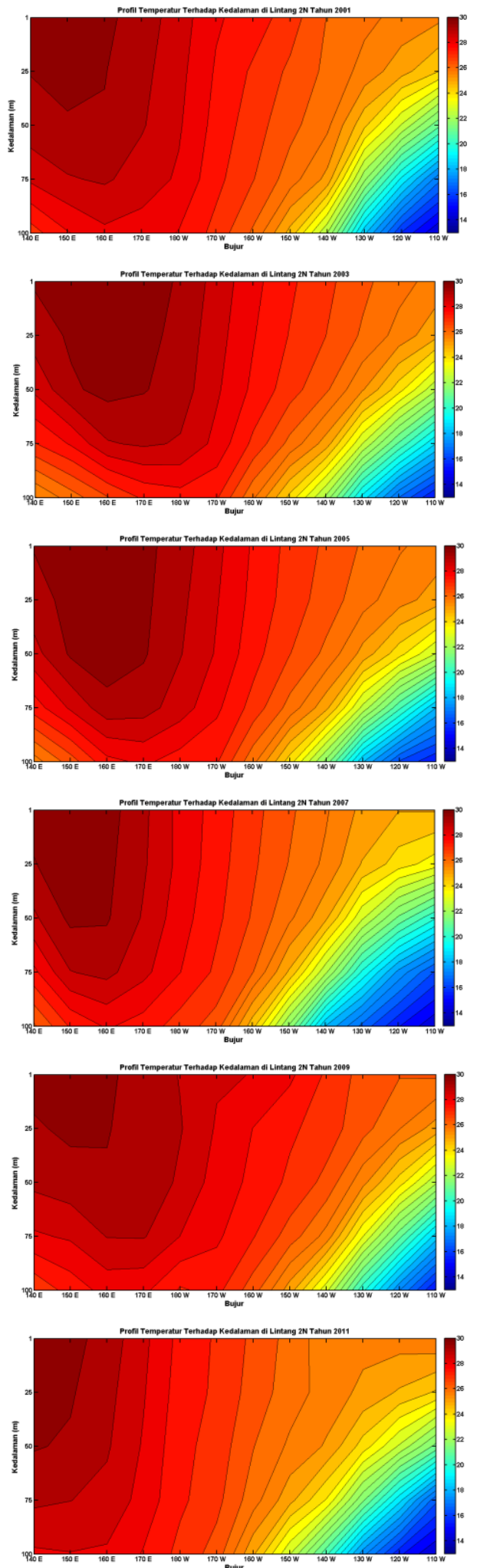

Gambar 5. Rata-rata tahunan suhu $\left({ }^{0} \mathrm{C}\right)$ pada tahun 2000-2012 di lintang $2{ }^{0} \mathrm{~N}$ Figure 5. Annual averaged of temperature $\left({ }^{\circ} \mathrm{C}\right)$ during 2000-2012 at $2{ }^{\circ} \mathrm{N}$ Sumber: Hasil pengolahan data 

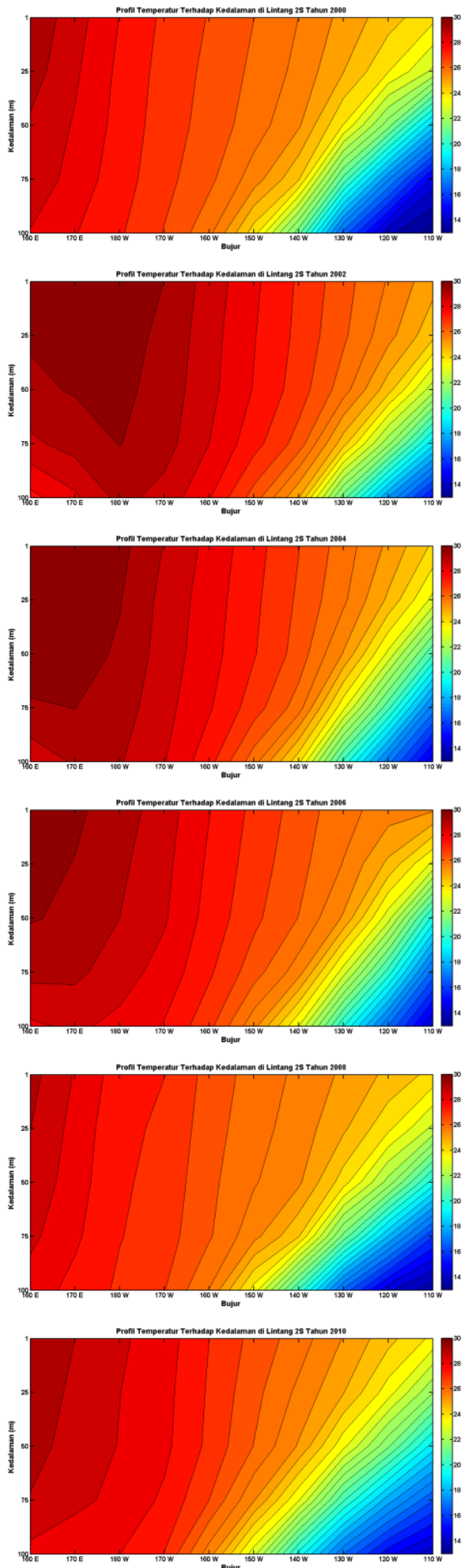
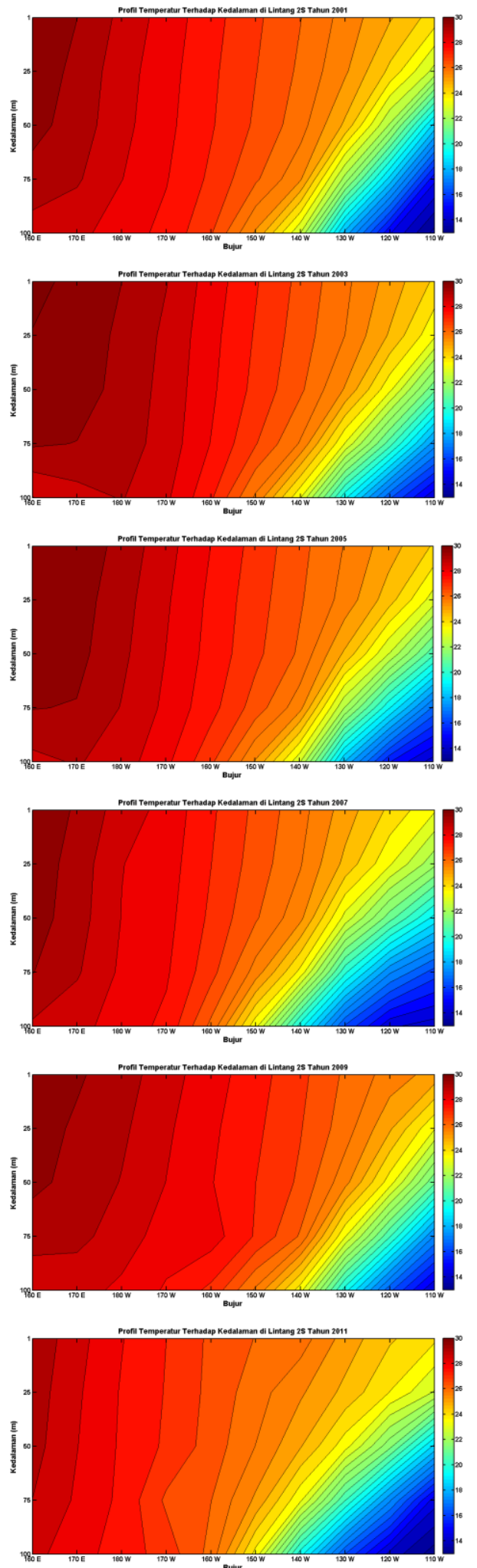

Gambar 6. Rata-rata tahunan suhu $\left({ }^{0} \mathrm{C}\right)$ pada tahun 2000-2012 di lintang $2{ }^{0} \mathrm{~S}$.

Figure 6. Annual averaged of temperature $\left({ }^{\circ} \mathrm{C}\right)$ during 2000-2012 at $2{ }^{\circ} \mathrm{S}$ Sumber: Hasil pengolahan data 

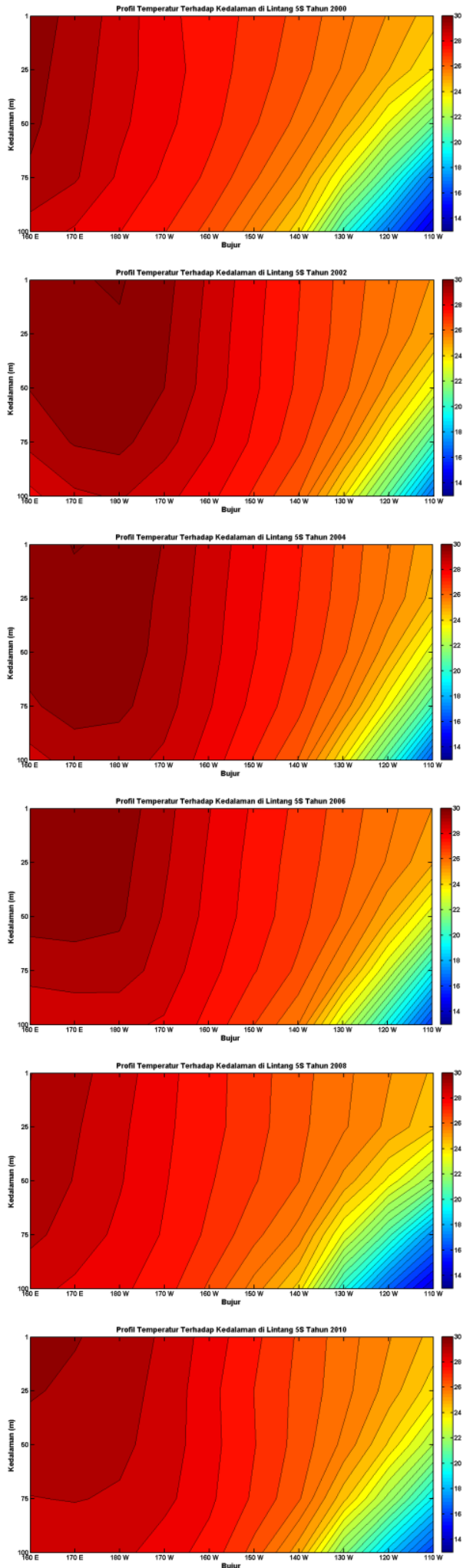
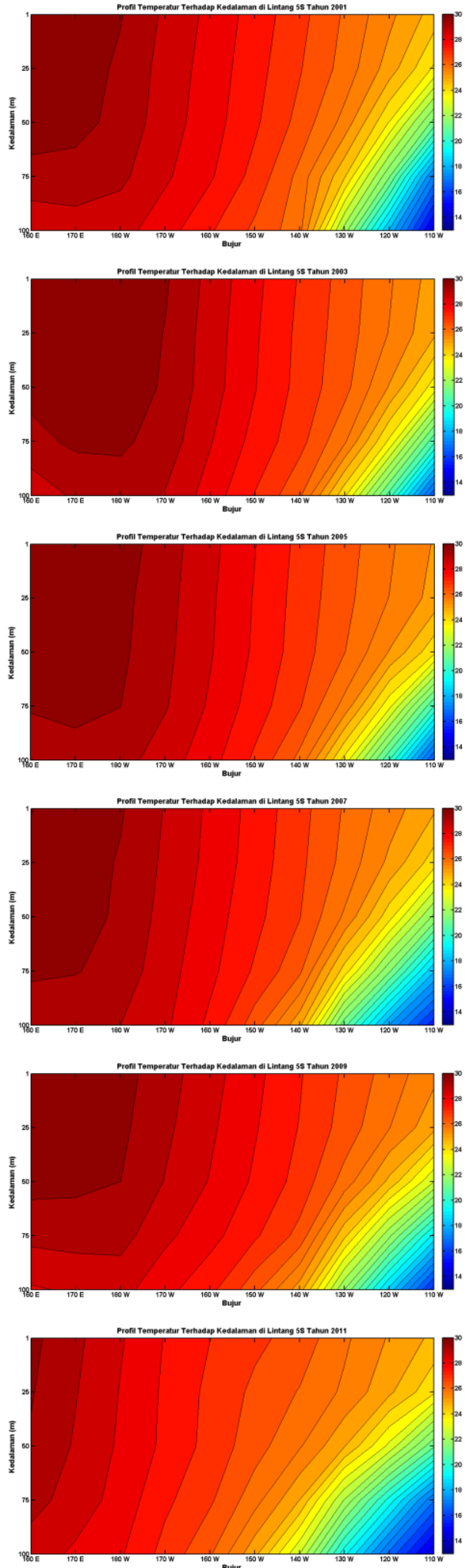

Gambar 7. Rata-rata tahunan suhu $\left({ }^{0} \mathrm{C}\right)$ pada tahun 2000-2012 di lintang 5S.

Figure 7. Annual averaged of temperature $\left({ }^{\circ} \mathrm{C}\right)$ during 2000-2012 at $5^{\circ} \mathrm{S}$ Sumber: Hasil pengolahan data 

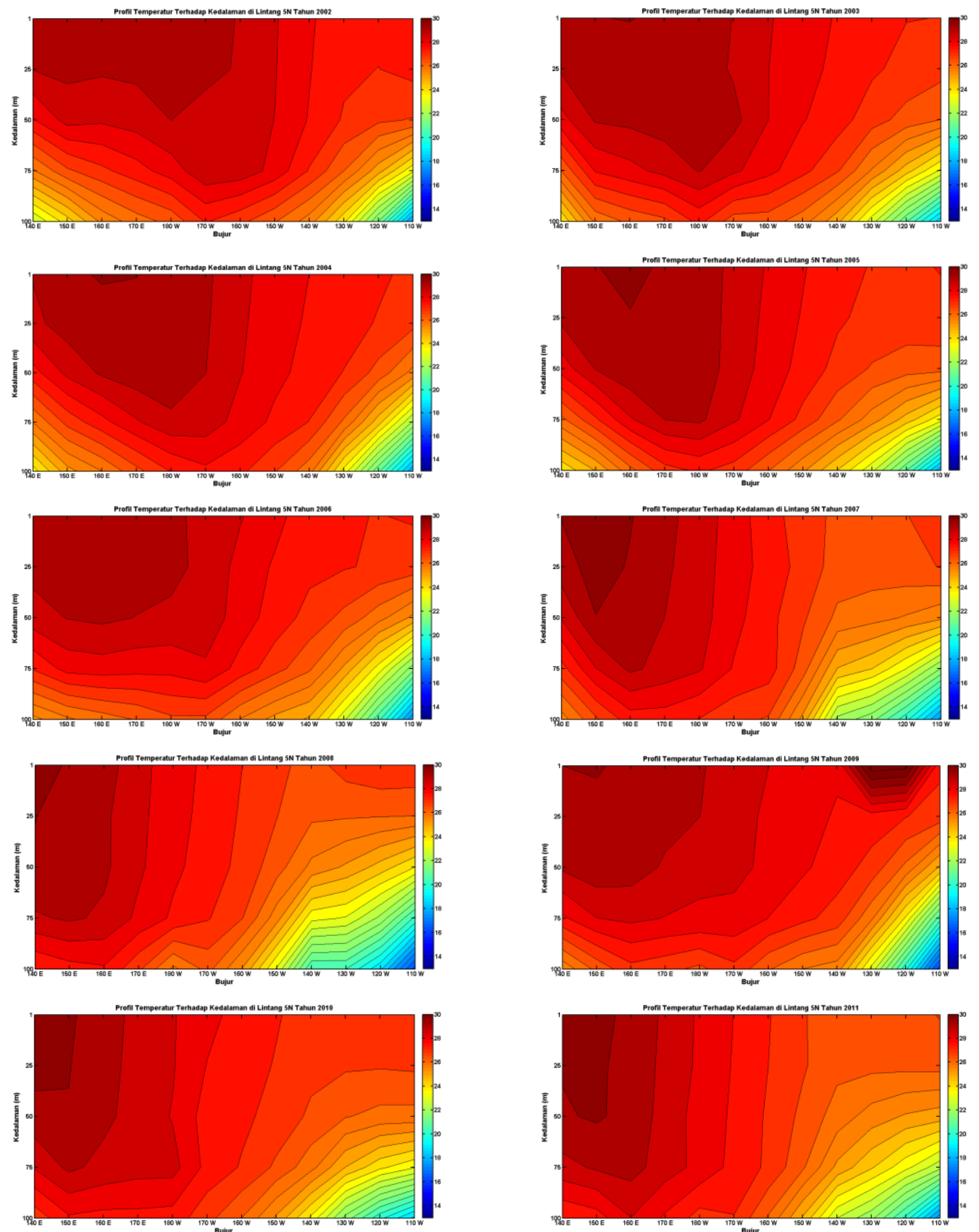

Gambar 8. Rata-rata tahunan suhu $\left({ }^{\circ} \mathrm{C}\right)$ pada tahun 2000-2012 di lintang 5N.

Figure 8. Annual averaged of temperature $\left({ }^{\circ} \mathrm{C}\right)$ during 2000-2012 at $5^{\circ} \mathrm{N}$

Sumber: Hasil pengolahan data 
a)

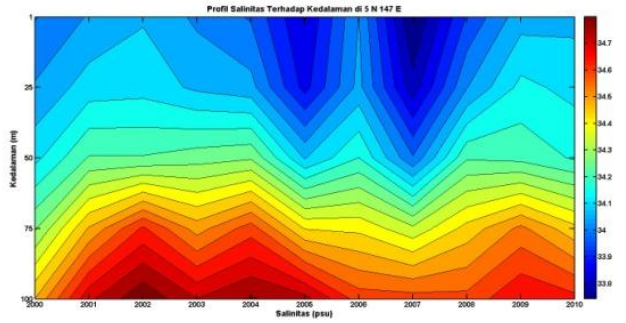

c)

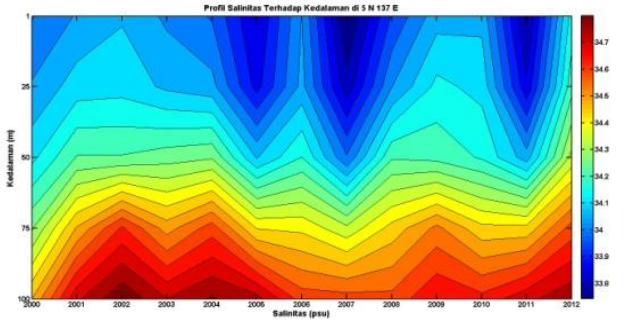

e)

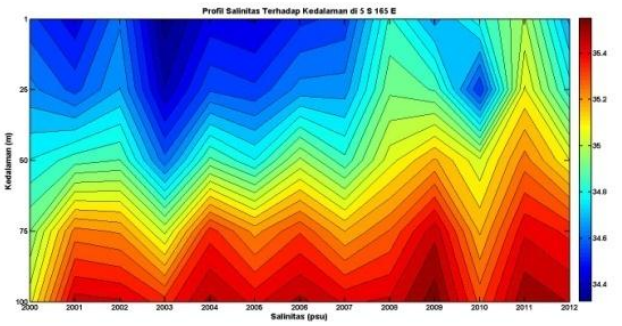

g)

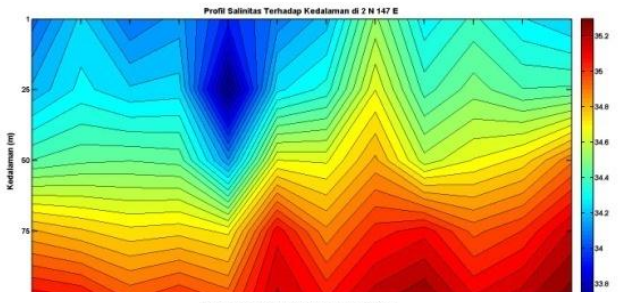

i)

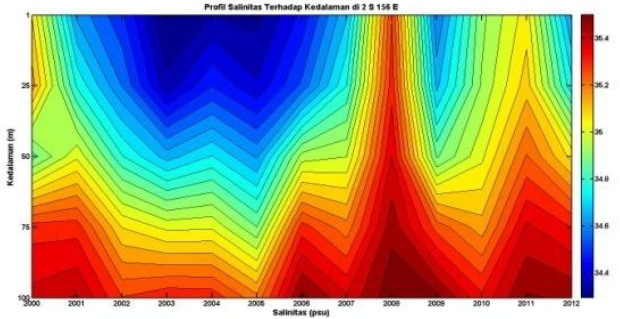

b)

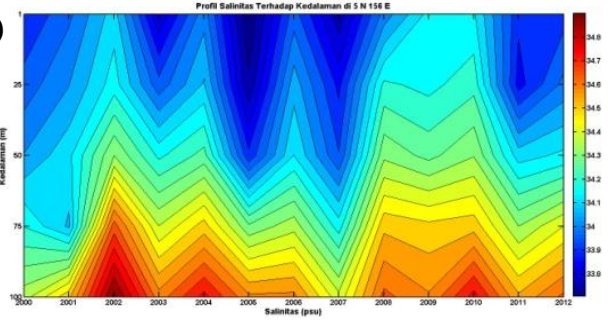

d)

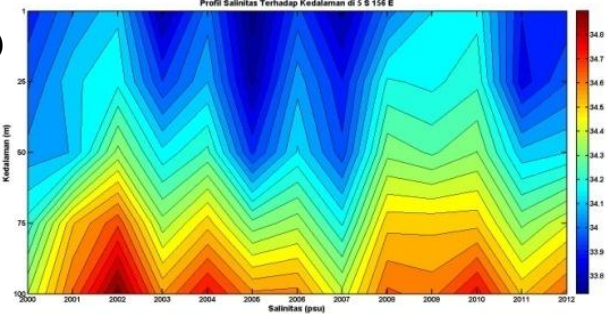

f)

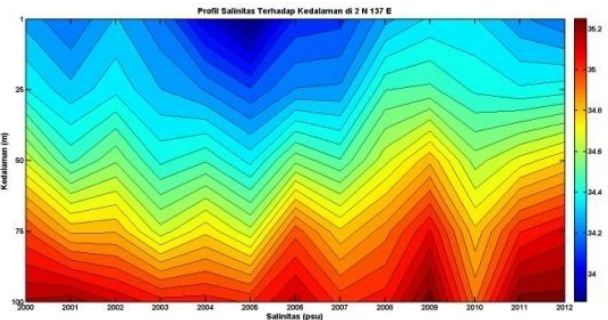

h)

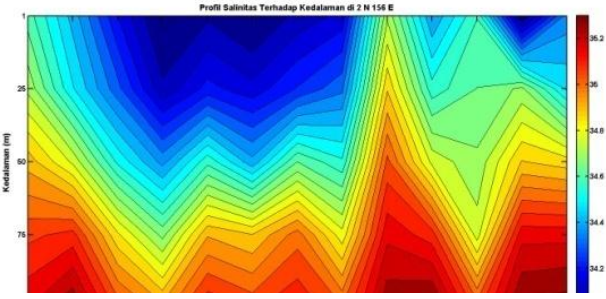

j)

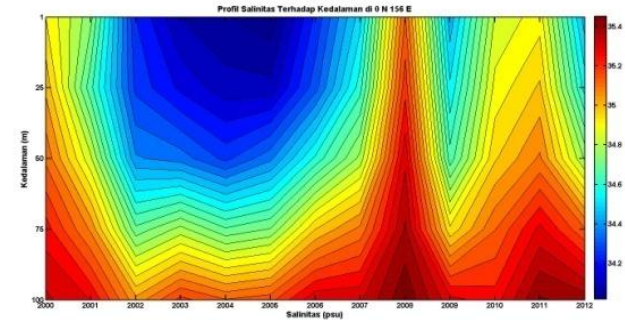

k)

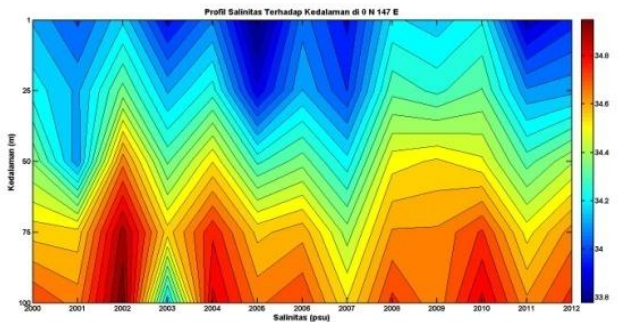

Gambar 9. Profil vertikal salinitas pada lintang $5 \mathrm{~N}(\mathrm{a}-\mathrm{c}), 5 \mathrm{~S}(\mathrm{~d}-\mathrm{e}), 2 \mathrm{~N}(\mathrm{f}-\mathrm{h}), 2 \mathrm{~S}$ (i) dan $0 \mathrm{~N}(\mathrm{j}-\mathrm{k})$.

Figure 9. Vertical profiles of salinity on longitude $5 N(a-c), 5 S(d-e), 2 N(f-h), 2 S(i)$ and $0 N(j-k)$

Sumber: Hasil pengolahan data 
Kondisi oseanografi selain suhu seperti salintas juga mempengaruhi keberadaan ikan cakalang. Pada daerah konvergensi, sangat ditentukan oleh suhu yang hangat $\left(26-29{ }^{0} \mathrm{C}\right)$ serta nilai salinitas yang rendah. Umumnya front salinitas yang berada di daerah tersebut berada pada isohalin 34,6 psu (Supangat et al., 2004). Nilai salinitas yang lebih rendah pada suhu hangat (warm low salinity) sangat disukai oleh ikan cakalang. Hasil pengolahan salinitas pada lintang $5 \mathrm{~N}, 5 \mathrm{~S}, 2 \mathrm{~N}, 2 \mathrm{~S}$ dan $0 \mathrm{~N}$ menunjukan variabilitas pada tiap kedalaman. Pada Gambar 9, terlihat nilai salinitas yang lebih rendah berada pada kedalaman 1-50 m; terutama pada tahun 2005, 2007, dan 2011. Hal tersebut mengindikasikan adanya pergerakan massa air vertikal berdasarkan tingkat salinitas dan fenomena La Nina.

Pada lokasi mooring TAO array yang dipetakan salinitasnya, memiliki massa air bersalinitas rendah dan terjadi pada tahun 2003, 2005, 2007 dan 2011. Fenomena ENSO, berdasarkan indeks SOI pada tahun 2003 (Gambar 2) terjadi El-Nino namun intensitasnya tidak kuat, hal yang sama juga terjadi pada tahun 2005. Pada tahun 2007, 2010 dan tahun 2011 terjadi La Nina. Kejadian La Nina yang kuat pada bulan Desembar 2010 berpengaruh terhadap ekuatorial Pasifik. Efeknya masih berpengaruh hingga tahun 2011 namun intensitasnya tidak sekuat tahun 2010. Daerah front terbentuk pada periode pergerakan zona konvergensi tahun 20022004 (Maes et al., 2006). Hasil analisis di atas menunjukkan daerah Barat Pasifik yang dicirikan oleh salinitas rendah yaitu 34,2-34,6 psu dan daerah Tengah hingga Timur Pasifik yang ditandai oleh nilai salinitas yang lebih tinggi (> 35,2 psu). Perbedaan tersebut juga lebih dikarenakan oleh fenomena ENSO. Front salinitas yang terbentuk adalah berkisar 34,6-35 psu dan berada pada 2-3 derajat dari daerah konvergen (Maes et al., 2005).

Terdapat hubungan yang kuat antara salinitas dengan klorofil-a di Samudera Pasifik. Nilai klorofil yang tinggi umumnya akan berasosiasi dengan salinitas yang rendah. Semakin tinggi stratifikasi salinitas, maka nilai klorofil-a akan semakin rendah (Maes et al., 2010). Maes et al., (2006) mengobservasi korelasi salinitas pada bujur $3{ }^{0} \mathrm{~N}-3{ }^{0} \mathrm{~S}$ di daerah ekuatorial dan hasilnya adalah terdapat gradien salinitas pada daerah $165{ }^{0} \mathrm{E}$ dan ditemukannya front salinitas dengan selang 34,635 psu lebih dari 2-3 derajat daerah transisi (eastern edge of equatorial pacific warm pool). Pengaruh angin juga sangat berpengaruh pada nilai salinitas. Front salinitas diatas merupakan lapisan yang terbentuk karena adanya pertemuan 2 (dua) massa air (subduksi) dari massa air yang bersalinitas tinggi yang berasal dari Tengah dan Timur Pasifik dengan massa air bersalinitas rendah dari Barat Pasifik.

\section{Pengaruh zona konvergensi terhadap hasil tangkapan ikan cakalang}

Pergerakan zona konvergensi di Barat Pasifik tentunya akan berpengaruh terhadap tangkapan ikan cakalang terutama di wilayah Indonesia, Kepulauan Filipina dan daerah sekitar $160{ }^{0} \mathrm{~W}$ (Lehodey et al., 2003). Uktolseja et al. (1989), penyebaran ikan cakalang di Indonesia meliputi Samudera Hindia (Perairan Barat Sumatera, Selatan Jawa, Bali, Nusa Tenggara), Perairan Indonesia bagian timur (Laut Sulawesi, Maluku, Arafuru, Banda, Flores dan Selat Makassar) dan Samudera Pasifik (Perairan Utara Irian Jaya). Pengaruh pergerakan zona konvergensi terhadap hasil tangkapan ikan cakalang dapat diketahui dengan melakukan analisa hubungan pergerakan zona konvergensi terhadap hasil tangkapan ikan cakalang di perairan Indonesia bagian Timur.

Gambar 10 menunjukkan hasil tangkapan ikan cakalang di Perairan Indonesia bagian Timur yang didaratkan di Kota Sorong maupun Provinsi Papua selama periode tahun 2007-2012 jika dikaitkan dengan fenomena ENSO. Pendataan hasil tangkapan ikan cakalang dilakukan oleh Dinas Kelautan dan Perikanan (DKP) Provinsi Papua dan Dinas Kelautan dan Perikanan Kota Sorong. Menurut data DKP tersebut, pada saat La-Nina, hasil tangkapan ikan cakalang cenderung menurun. Pada tahun 2008 saat terjadi La-Nina SOI berada pada batas atas threshold (> 8). Fenomena La-Nina mempunyai intensitas yang tinggi pada awal tahun 2008 kemudian melemah hingga bulan Juli 2008. La-Nina yang terjadi ini berdampak pada perikanan cakalang di Provinsi Papua, dimana hasil tangkapan ikan cakalang menurun hingga $1.611 \mathrm{~kg}$ khususnya pada bulan Januari 2008. Seiring dengan berkurang atau melemahnya LaNina, ikan cakalang yang tertangkap di Papua meningkat hingga puncaknya mencapai pada bulan Mei 2008 dengan hasil tangkapan mencapai 33.183 kg. Berbeda dengan tangkapan di Provinsi Papua, hasil tangkapan yang didaratkan di Kota Sorong 
menunjukan pola yang terbalik. Pada saat La-Nina, hasil tangkapan meningkat pada tahun 2008 khususnya pada bulan Maret yang mencapai $18.480 \mathrm{~kg}$. Pada saat La-Nina melemah, hasil tangkapan cenderung menurun hingga mencapai $3.745 \mathrm{~kg}$ pada bulan Juli 2008. Efek dari kejadian La-Nina terhadap hasil tangkapan ikan cakalang terjadi juga pada bulan September 2009-Januari 2010 dimana terdapat hubungan positif dan negatif terhadap musim tangkapan di kedua kota tersebut.

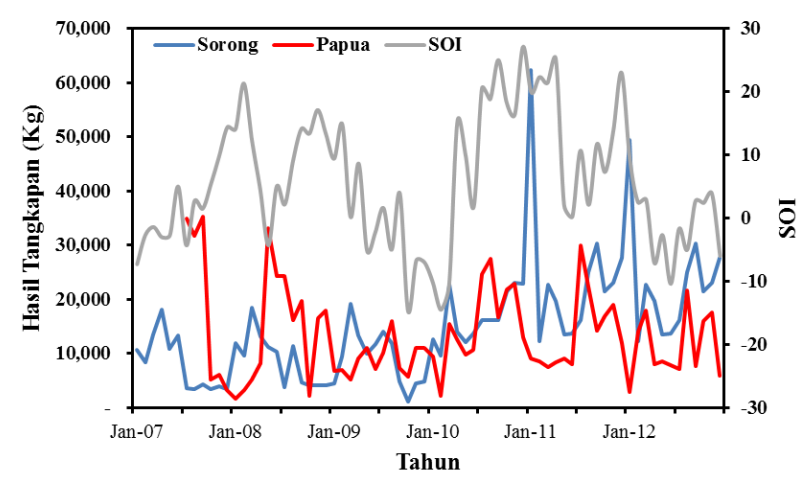

Gambar 10. Hubungan hasil tangkapan ikan cakalang dengan SOI di Kota Sorong dan Provinsi Papua tahun 2007-2012.

Figure 10. Relationship between skipjack tuna catchment in Sorong City and Papua Province related to SOI during 2007-2012 Sumber: Hasil analisis

Berdasarkan Gambar 10, fenomena El-Nino terjadi mulai bulan Juni tahun 2009 hingga mencapai puncaknya pada bulan Desember 2009 - Februari 2010. Pada saat itu, SOI memperlihatkan nilai di bawah batas $(<-8)$. Jika dikaitkan pengaruh ElNino, hasil tangkapan ikan cakalang di Kota Sorong berfluktuasi. Pada bulan Juli 2009, hasil tangkapan ikan cakalang mencapai $14.010 \mathrm{~kg}$ kemudian berfluktuasi hingga bulan Januari 2010 sebesar $12.700 \mathrm{~kg}$. Walaupun El-Nino mulai melemah, ikan cakalang yang tertangkap masih menunjukan nilai yang tinggi. Hal ini bisa dilihat pada bulan Maret 2010 dimana hasil tangkapan mencapai $22.765 \mathrm{~kg}$. Pola yang linear antara SOI dengan hasil tangkapan di kedua lokasi pendaratan ikan terlihat pada pertengahan 2012. Pendaratan ikan cakalang di Kota Sorong pada periode tersebut mencapai $30.325 \mathrm{~kg}$ dan di Provinsi Papua mencapai $21.625 \mathrm{~kg}$.

\section{KESIMPULAN DAN SARAN}

Zona konvergensi bergeser ke arah Timur Barat Pasifik akibat pengaruh ENSO. Pergerakan horizontal massa air hangat kearah Barat Pasifik dan pergerakan vertikal dari kedalaman $25 \mathrm{~m}$ hingga $75 \mathrm{~m}$ khususnya pada isoterm $29{ }^{\circ} \mathrm{C}$ terjadi saat La Nina. Hal yang sama juga terjadi pada salinitas dimana nilai yang rendah bergerak secara vertikal hingga kedalaman $50 \mathrm{~m}$.

\section{UCAPAN TERIMA KASIH}

Penelitian ini merupakan bagian dari kegiatan di Balai Penelitian dan Observasi Laut, Balitbang KP, KKP. Ucapan terima kasih ditujukan kepada Ibu Mutiara R. Putri dan Bapak Budi Nugraha atas diskusinya terkait dengan penelitian ini dan Suliskania Safitri atas bantuan pengolahan data TAO/TRITON.

\section{DAFTAR PUSTAKA}

Andrade, H.A., \& Garcias, C.A.E. (1999). Skipjack tuna fishery in relation to sea surface temperature off the southern Brazilian coast. Fisheries Oceanography, 8:4, 245-254.

Barkley, R.A., Neil, W.N., \& Gooding, R.M. (1978). Skipjack tuna, katsuwunos pelamis, habitat based on temperature and oxygen requirements. Fish Bull, 78(3), 653-662.

Behrenfeld, M.J., \& Falkowski, P.G. (1997). Photosynthetic rates derived from satellite-based chlorophyll concentration. Limnology and Oceanography, 42(1), 1-20.

Brill, R., Bigelow, K., Musyl, M., Fritsches, K., \& Warrant, E. (2005). Bigeye tuna (Thunnus obesus) behavior and physiology and their relevance to stock assessment and fishery biology. Collected Volume of Scientific Papers, International Commission for the Conservation of Atlantic Tunas, 57(2), 142-161.

Bunyamin, E.K. (1981). Suatu studi tentang Skipjack dan penyebarannya di perairan Sorong dan sekitarnya. Skripsi. Fakultas Perikanan, IPB Bogor. 108 hal.

Chavez, F.P., Strutton, P.G., Freidrich, G.E., Feely, R. A., Feldman, G.C., Foley, D.G., \& McPhaden, M.J. (1999). Biological and chemical response of the equatorial Pacific Ocean to the 1997-98 El Nino. Science, 286, 2126-2131.

Dizon, A.E. (1977). Effect of dissolved oxygen concentration and salinity on swimming speed of 
two species of tunas. Fish. Bull., U.S., 75, 649653.

Grandperrin, R. (1978). Influence of currents on the production of tropical seas: consequences for fisheries. Fisheries Newsletter, No. 17, South Pacific Commission, Noumea, New Caledonia. pp $14-20$.

Gunarso, W. (1985). Tingkah laku ıkan dalam hubungannya dengan alat, metode dan taktik penangkapan. Skripsi. Fakultas Perikanan. Institut Pertanian Bogor. Bogor. 149 hal.

http://oceandata.sci.gsfc.nasa.gov/.diakses pada tanggal 29 Januari 2013.

http://pmel.noaa.gov/tao/.diakses pada tanggal 11 Juni 2013.

http://science.oregonstate.edu/ocean.productivity/index. php. diakses pada tanggal 31 Januari 2013.

http://www.r-project.org/. diakses pada tanggal 2 Juni 2013.

Lamigueiro, O.P., \& Hijmans, R. (2013). RasterVis: Visualization methods for the raster package. $\mathrm{R}$ package version 0.20-07. http://CRAN.Rproject.org/package $=$ rasterVis

Lehodey, P., Bertignac, M., Hampton, J., Lewis, A., \& Picaut, J. (1997). El Nino Southern Oscillation and Tuna in Western Pacific. Nature, 389, 715718.

Lehodey, P., Chai, F., \& Hampton, J. (2003). Modelling climate-related variability of tuna populations from a coupled ocean biogeochemical-population dynamics model. Fish. Oceanogr., 12, 483-494.

Limbong, M. (2008). Pengaruh suhu permukaan laut terhadap jumlah dan ukuran hasil tangkapan ikan cakalang di perairan Teluk Palabuhanratu Jawa Barat. Skripsi. Departemen Pemanfaatan Sumberdaya Perikanan, Fakultas Perikanan dan Ilmu Kelautan, Institut Pertanian Bogor. Bogor. 77 hal.

Maes, C., Picaut, J., \& Belamari, S. (2005). Importance of salinity barrier layer for the buildup of El Nino. Journal of Climate, 18, 104-118.

Maes, C., Ando, K., Delcroix, T., Kessler, W.S., McPhaden, M.J., \& Roemmich, D. (2006). Observed correlation of surface salinity, temperature and barrier layer at Eastern edge of Western Pasific Warm Pool. Geophysical Research Letter, 33, L06601, 1-4.

Maes, C., Sudre, J., \& Veronique, G. (2010). Detection of the Eastern of the Equatorial Warm Pool using satellite-based ocean color observations. Sola, 6, 129-132.

Matsumoto, K., \& Ando, K. (2009). Use of cyanobacterial pigments to charachterize the ocean surface mixed layer in the Pacific Warm Pool. J. Mar. Syst., 75, 245-252.

Picaut, J., Loualalen, M., Menkes, C., Delcroix, T., \& McPhaden, M.J. (1996). Mechanism of zonal displacement of the Pacific warm pool: implication for ENSO. Science, 274, 1486-1489.

Setiawan, A. (2002). Analysis of meteorologyoceanography parameters variability in the maritime continent of Indonesia and their relationship to the ENSO and dipole mode phenomena. Master thesis. Bandung Institute of Technology. 60p.

Stewart, R.H. (2002). Introduction to Physical Oceanography. Spring 2002 Edition, 341 pp

Supangat, A., Adi, T.R., Pranowo, W.S., \& Ningsih, N.S. (2004). Predicting movement of the Warm Pool, the salinity front and the convergence zone in the Western and Central part of Equatorial Pacific using a coupled hydrodinamicalecological model. The twelfth OMISAR Workshop on Ocean Model. 11, 1-11.

Uktolseja, J.C.B., Purwasasmita, R., Susanto, K., \& Sulistiadji, A.B. (1989). Sumberdaya ikan pelagis besar. Dalam Potensi dan penyebaran sumberdaya ikan laut di perairan Indonesia. Komisi Nasional Pengkajian Stok Sumberdaya Ikan Laut, Lembaga Ilmu Pengetahuan Indonesia dan Direktorat Jenderal Perikanan. Jakarta. Hal 40-88.

Waas, H.J.D. (2004). Analisis daerah potensial penangkapan Cakalang (Katsuwonus pelamis) dan Madidihang (Thunnus albacares) di perairan Utara Papua, Pasifik Barat. Tesis. Sekolah Pasca Sarjana. Institut Pertanian Bogor. Bogor. 102 hal. 